\title{
Essential epidemiological parameters of COVID-19 for clinical and mathematical modeling purposes: a rapid review and meta-analysis
}

Eva S. Fonfría ${ }^{1}$, Ph.D., María Isabel Vigo ${ }^{2}$, Ph.D., David García-García ${ }^{2}$, Ph.D., Zaida Herrador ${ }^{3}$, M.D., Ph.D., Miriam Navarro ${ }^{1,4}$, M.D., Ph.D., Cesar Bordehore, Ph.D. ${ }^{1,5}$

${ }^{1}$ Multidisciplinary Institute for Environmental Studies "Ramon Margalef”, University of Alicante, Alicante, Spain.

${ }^{2}$ Department of Applied Mathematics, University of Alicante, Alicante, Spain.

${ }^{3}$ National Centre of Tropical Medicine, Instituto de Salud Carlos III, Madrid, Spain.

${ }^{4}$ Department of Public Health, Science History and Gynecology, Universidad Miguel Hernández, Alicante, Spain

${ }^{5}$ Department of Ecology, University of Alicante, Alicante, Spain.

Keywords: COVID-19, epidemiological parameters, mathematical modeling, review, meta-analysis Running title: Epidemiological parameters of COVID-19

Corresponding author:

Dr. Cesar Bordehore

Department of Ecology, University of Alicante, Campus San Vicente del Raspeig, 03690, Spain

Tel: +34 652995524, Fax: +34 965903625

cesar.bordehore@ua.es

Alternate corresponding author:

Dr. Eva Fonfría

"Ramon Margalef" Environmental Research Institute (IMEM), University of Alicante, Campus San Vicente del Raspeig, 03690, Spain

Tel: +34 626601662, Fax: +34 965903625

eva.fonfria@ua.es 
medRxiv preprint doi: https://doi.org/10.1101/2020.06.17.20133587; this version posted June 19, 2020. The copyright holder for this preprint (which was not certified by peer review) is the author/funder, who has granted medRxiv a license to display the preprint in perpetuity.

It is made available under a CC-BY-NC-ND 4.0 International license .

\section{Abstract}

We present a literature review and meta-analysis of relevant epidemiological parameters $(24$ for adults, 7 for children) of COVID-19. Standardization of these parameters is key to performing valid clinical and mathematical modeling, as well as forecasts, helping us to improve our understanding about the characteristics and impact of the pandemic.

\section{Text}

Without any doubt, the coronavirus disease 2019 (COVID-19) outbreak, caused by the novel coronavirus SARS-CoV-2, is the most significant global public health threat in recent decades. It was declared as "Public Health Emergency of International Concern" and "pandemic" by the World Health Organization (WHO) in 30 January and 11 March 2020, respectively. Since it was first detected December 2019 in Wuhan, China, it has spread over 212 countries and territories, with almost $6,800,000$ confirmed cases and 400,000 deaths worldwide as of 7 June 2020 [1].

In the absence of effective treatments or preventative therapeutic strategies for COVID-19 [2], epidemiological models have become key tools for policymakers and stakeholders to estimate the probable time course of the pandemic and to evaluate the effectiveness of the measures adopted to manage it [3-5]. Since the beginning of the pandemic, thousands of preprints and papers have been published about COVID-19. However, sample sizes were usually too small to be able to generalize the values and to enable better models and evidence-based clinical decisions. It is desirable that those parameters be defined and determined as accurately as possible, taking into account the inter-study variability with the appropriate mathematical methodology. Besides, most studies so far examine only a handful of variables, making data mining particularly onerous and tedious. The aim of this study is to identify and summarize the key epidemiological parameters used so far for mathematical modeling and clinical purposes. 
medRxiv preprint doi: https://doi.org/10.1101/2020.06.17.20133587; this version posted June 19, 2020. The copyright holder for this preprint (which was not certified by peer review) is the author/funder, who has granted medRxiv a license to display the preprint in perpetuity.

It is made available under a CC-BY-NC-ND 4.0 International license .

We searched PubMed, MedRxiv and BioRxiv for articles and preprints published in English between 1 January and 15 April 2020 with the keywords "COVID-19", "SARS-CoV-2", "2019-nCoV" or "novel coronavirus" as well as terms to obtain data about the following parameters (definitions and reclassifications are described in the Supplementary Material): percentage of presymptomatic transmissions, presymptomatic transmission period, percentage of asymptomatic patients, serial interval, incubation period, onset of symptoms/illness onset to diagnosis, onset of symptoms/illness onset to hospital admission, hospital stay length, hospital admission to death, hospital admission to discharge, onset of symptoms/illness onset to death, onset of symptoms/illness onset to discharge/recovery, percentage of deaths, percentage of discharged, percentage in hospital, percentage of Intensive Care Unit (ICU) admissions, onset of symptoms/illness onset to ICU admission, ICU stay length, percentage of deaths from ICU, percentage of discharged from ICU, percentage in hospital from ICU, and percentage transferred from ICU to general hospital wards.

A preliminary screening by title and abstract was conducted to identify potentially relevant studies. Subsequently, the full texts of those studies were evaluated and their reference lists examined for additional records (see Supplementary Figure 1 for the flow diagram). Relevant epidemiological parameters, such as sample size, mean, standard deviation (SD), confidence interval (CI), median, interquartile range (IQR) and the fitted distribution used in its estimation, when applicable, as well as sociodemographic information (i.e. patient's age, gender and location) were extracted. Reviews and non-original research papers were excluded. In case of data overlap (e.g. several studies reported data about "asymptomatic patients" among passengers of the Diamond Princess cruise ship), the article with the largest sample size was chosen. Finally, because COVID-19 does not seem to affect children and teens in the same way as adults [6], we decided to analyze the obtained data for pediatric patients separately. Initial screening was performed by ESF, followed by an ultimate extraction of data assessed independently by ESF, DGG and MIV. When discrepancies were detected, MIV made the final inclusion decision. 
medRxiv preprint doi: https://doi.org/10.1101/2020.06.17.20133587; this version posted June 19, 2020. The copyright holder for this preprint (which was not certified by peer review) is the author/funder, who has granted medRxiv a license to display the preprint in perpetuity.

It is made available under a CC-BY-NC-ND 4.0 International license .

To integrate all the reviewed information in one overall estimate that could be introduced in mathematical models, we performed different meta-analysis (see Supplementary Material for detailed information). For those parameters including mean and SD, or median and IQR, we carried out a meta-analysis of single means; when mean and SD were not reported, they were estimated from median and IQR $[7,8]$. For those parameters presented as percentages, a meta-analysis of proportions was implemented. To take into account the variability between and within studies, random-effects models were fitted with the Restricted Maximum Likelihood Method (REML). To meet the normality assumption underlying the meta-analysis, the natural logarithm transformation was applied. The null hypothesis of no variance among studies $\left(\tau^{2}=0\right)$ was tested using the $Q$ statistic, and the degree of heterogeneity was quantified by the $I^{2}$ index [9]. Outliers and influencers diagnoses were also performed [10]. Data were analyzed using the statistical software $\mathrm{R}$ version 3.6.2 and the "meta", "metaphor" and "dmetar" packages.

Between 1 January and 15 April 2020, 6,969 scientific articles related to COVID-19 were published in Pubmed or posted in MedRxiv and BioRxiv preprint servers. After filtering using the aforementioned keywords and terms and performing the initial screening of titles and abstracts, a total of 343 papers were reviewed in full text. From them, 126 contained extractable data (see Supplementary Table 1), 118 were considered initially in our meta-analysis for one or more parameters and after removing outliers/influencers, 102 were included in the final analysis. Table 1 shows the pooled mean or percentage and its associated $95 \% \mathrm{Cl}$ provided by the meta-analysis for parameters with three or more studies, i.e., 18 parameters ( 3 of them disaggregated in survivor/non-survivor) for the general population and 7 for children. For each parameter, forest plots to visualize results when all the studies were included in the meta-analysis and with outliers and/or influencers removed are provided in the Supplementary Material (Supplementary Figures 2-32). For most parameters, the heterogeneity was moderate to high. 
medRxiv preprint doi: https://doi.org/10.1101/2020.06.17.20133587; this version posted June 19, 2020. The copyright holder for this preprint (which was not certified by peer review) is the author/funder, who has granted medRxiv a license to display the preprint in perpetuity.

It is made available under a CC-BY-NC-ND 4.0 International license .

Compared to other available reviews on COVID-19 [11,12], our study summarized a larger number of epidemiological parameters and covered a longer period of time, substantially increasing the number of studies considered per parameter. This study also has several limitations. First, only papers in the English language were evaluated. Although many papers have been published in Chinese and a few in other languages, papers in English provided a large enough sample. Second, we performed the search strategy only in three libraries and up to 15 April 2020. We realize our work might not include all the published data with the selected parameters; however, the number of papers about COVID-19 posted daily is so large that any attempt to perform an in-depth systematic review would be rapidly outdated. Finally, we included preprints, which, although they had not yet been peer-reviewed and their results should be interpreted cautiously, contain valuable information.

In summary, we present a review of the most relevant epidemiological parameters of COVID-19 so far. Our results will promote reliable and more accurate forecasts using mathematical modeling of the epidemic itself and also of the material and human resources needed. These data may also be of interest to clinicians, e.g. for their daily work, interpretation of clinical evolution, or clinical trials design. We expect it to be useful to other modelers, managers, and national and regional policy makers when deciding the appropriate mitigation strategies for the ongoing global pandemic.

\section{Funding}

This work was supported by the University of Alicante [COVID-19 2020-41.30.6P.0016 to CB] and the Ajuntament de Dénia through the Montó-Dénia Research Station Agreement [2020-41.30.60.00.01 to $\mathrm{CB}$ ].

\section{Acknowledgements}


medRxiv preprint doi: https://doi.org/10.1101/2020.06.17.20133587; this version posted June 19, 2020. The copyright holder for this preprint (which was not certified by peer review) is the author/funder, who has granted medRxiv a license to display the preprint in perpetuity.

It is made available under a CC-BY-NC-ND 4.0 International license .

We acknowledge Parques Nacionales (Ministerio para la Transición Ecológica y Reto Demográfico, Spain) and Generalitat Valenciana (Regional Government of Valencia, Spain) for the support of the Montgó-Dénia Research Station. Editing was provided by Sea Pen Scientific Writing.

\section{References}

1. WHO. Coronavirus disease (COVID-19). Situation Report - 139. 2020. Available at:

https://www.who.int/docs/default-source/coronaviruse/situation-reports/20200607\%0Acovid-19-sitrep-139.pdf?sfursn=79dc6d08_2. Accessed 8/6/2020.

2. Lythgoe MP, Middleton P. Ongoing Clinical Trials for the Management of the COVID-19 Pandemic. Trends Pharmacol. Sci. 2020;

3. Bordehore C, Herrador Z, Fonfria ES, Navarro M. Understanding COVID-19 spreading through simulation modeling and scenarios comparison: preliminary results. medRxiv 2020;

:2020.03.30.20047043. Available at:

https://www.medrxiv.org/content/10.1101/2020.03.30.20047043v1.full.pdf.

4. Filho TMR, Santos FSG dos, Gomes VB, et al. Expected impact of COVID-19 outbreak in a major metropolitan area in Brazil. medRxiv 2020; :2020.03.14.20035873-

2020.03.14.20035873. Available at:

https://www.medrxiv.org/content/10.1101/2020.03.14.20035873v1.full.pdf.

5. Holmdahl I, Buckee C. Wrong but Useful - What Covid-19 Epidemiologic Models Can and Cannot Tell Us. N Engl J Med 2020;

6. Du W, Yu J, Wang H, et al. Clinical characteristics of COVID-19 in children compared with adults in Shandong Province, China. Infection 2020;

7. Luo D, Wan X, Liu J, Tong T. Optimally estimating the sample mean from the sample size, 
medRxiv preprint doi: https://doi.org/10.1101/2020.06.17.20133587; this version posted June 19, 2020. The copyright holder for this preprint (which was not certified by peer review) is the author/funder, who has granted medRxiv a license to display the preprint in perpetuity.

It is made available under a CC-BY-NC-ND 4.0 International license.

median, mid-range, and/or mid-quartile range. Stat Methods Med Res 2018; 27:1785-1805.

8. Wan X, Wang W, Liu J, Tong T. Estimating the sample mean and standard deviation from the sample size, median, range and/or interquartile range. BMC Med Res Methodol 2014; 14.

9. Higgins JPT, Thompson SG. Quantifying heterogeneity in a meta-analysis. Stat Med 2002; 21:1539-1558.

10. Viechtbauer W, Cheung MW-L. Outlier and influence diagnostics for meta-analysis. Res Synth Methods 2010; 1:112-125.

11. Park M, Cook AR, Lim JT, Sun Y, Dickens BL. A Systematic Review of COVID-19 Epidemiology Based on Current Evidence. J Clin Med 2020; 9:967.

12. Khalili M, Karamouzian M, Nasiri N, Javadi S, Mirzazadeh A, Sharifi H. Epidemiological Characteristics of COVID-19: A Systemic Review and Meta-Analysis. medRxiv 2020; :2020.04.01.20050138. Available at:

http://medrxiv.org/content/early/2020/04/06/2020.04.01.20050138. 
medRxiv preprint doi: https://doi.org/10.1101/2020.06.17.20133587; this version posted June 19, 2020. The copyright holder for this preprint (which was not certified by peer review) is the author/funder, who has granted medRxiv a license to display the preprint in perpetuity.

It is made available under a CC-BY-NC-ND 4.0 International license .

\section{Tables}

Table 1. Meta-analysis results.

\begin{tabular}{|c|c|c|c|c|}
\hline Parameter & Mean & $95 \% \mathrm{Cl}$ & $\begin{array}{c}\text { Studies } \\
\text { included* }\end{array}$ & $\begin{array}{c}\mathrm{N} \\
\text { (patients) }\end{array}$ \\
\hline \multicolumn{5}{|l|}{ General population } \\
\hline Serial interval (days) & 5.06 & $4.50-5.70$ & 11 & 852 \\
\hline Incubation period (days) & 5.79 & $5.48-6.11$ & 21 & 1792 \\
\hline Onset of symptoms to diagnosis (days) & 5.82 & 4.74-7.15 & 7 & 814 \\
\hline Onset of symptoms to hospital admission (all) (days) & 6.49 & $5.94-7.10$ & 14 & 1544 \\
\hline Onset of symptoms to hospital admission (survivor) (days) & 6.60 & $4.23-10.29$ & 3 & 314 \\
\hline Onset of symptoms to hospital admission (non-survivor) (days) & 10.18 & $9.65-10.74$ & 6 & 569 \\
\hline Onset of symptoms to hospital ICU admission (all) (days) & 9.69 & $9.14-10.26$ & 5 & 174 \\
\hline Hospital stay length (all) (days) & 14.21 & $13.38-15.10$ & 7 & 991 \\
\hline Hospital stay length (non-survivor) (days) & 9.16 & $8.29-10.13$ & 9 & 453 \\
\hline Hospital stay length (survivor) (days) & 15.21 & $14.37-16.10$ & 12 & 737 \\
\hline ICU stay length (all) ** (days) & 8.72 & 7.57-10.05 & 3 & 414 \\
\hline ICU stay length (non-survivor) (days) & 8.16 & $7.26-9.17$ & 5 & 371 \\
\hline ICU stay length (survivor) (days) & 10.91 & $9.20-12.94$ & 4 & 87 \\
\hline Onset of symptoms to death (days) & 16.71 & $15.37-18.17$ & 11 & 601 \\
\hline Onset of symptom to discharge $* *$ (days) & 21.83 & $19.20-24.85$ & 4 & 522 \\
\hline Presymptomatic transmission (\%) & 39.04 & $18.38-64.56$ & 4 & 713 \\
\hline Asymptomatic patients (\%) & 8.99 & $5.58-14.18$ & 17 & 2304 \\
\hline ICU admissions vs all COVID-19 hospital admissions (\%) & 18.16 & $15.74-20.86$ & 12 & 5877 \\
\hline Deaths vs all hospitalized patients with COVID-19 (\%) & 9.16 & $6.91-12.03$ & 14 & 2608 \\
\hline Deaths from ICU (\%) & 29.17 & $14.69-49.62$ & 8 & 555 \\
\hline Discharged vs all hospitalized patients with COVID-19 (\%) & 42.79 & $36.76-49.05$ & 15 & 4064 \\
\hline Discharged from ICU (\%) & 35.31 & $21.56-52.00$ & 9 & 565 \\
\hline
\end{tabular}


medRxiv preprint doi: https://doi.org/10.1101/2020.06.17.20133587; this version posted June 19, 2020. The copyright holder for this preprint (which was not certified by peer review) is the author/funder, who has granted medRxiv a license to display the preprint in perpetuity.

It is made available under a CC-BY-NC-ND 4.0 International license .

\begin{tabular}{|c|c|c|c|c|}
\hline In hospital (\%) & 53.92 & $46.81-60.86$ & 16 & 4181 \\
\hline In hospital (ICU) (\%) & 20.14 & $12.29-31.21$ & 8 & 238 \\
\hline \multicolumn{5}{|l|}{ Children (<18 years) } \\
\hline Incubation period $* *$ (days) & 6.69 & $5.49-8.15$ & 4 & 25 \\
\hline Onset of symptoms to diagnosis ** (days) & 3.27 & $1.35-7.92$ & 3 & 744 \\
\hline Hospital stay length ** (days) & 12.77 & $8.51-19.17$ & 3 & 52 \\
\hline Asymptomatic patients ** (\%) & 16.66 & $11.52-23.48$ & 4 & 945 \\
\hline ICU admissions vs all COVID-19 hospital admissions ** (\%) & 5.06 & $1.64-14.60$ & 4 & 211 \\
\hline Discharged vs all hospitalized patients with COVID-19 ** (\%) & 19.39 & $3.39-62.23$ & 3 & 205 \\
\hline In hospital **(\%) & 80.27 & $37.87-96.45$ & 3 & 205 \\
\hline
\end{tabular}

Abbreviations: $\mathrm{Cl}$, Confidence Interval; ICU, Intensive Care Unit.

* References are compiled in the Supplementary Appendix (Table S2).

** Results are based in less than 5 studies and they have to be interpreted cautiously. Outliers and influencers analysis is not included because it is useless. 